of domestic production with high efficiency and wide variation of dosage forms remains a topical issue.

\title{
References:
}

1. Князькова I.I. Сучасні підходи до діагностики анемій. Ліки Украӥни. № 7. 2010. С. 52-56.

2. Мнушко 3.Н., Пестун И.В. Теория и практика маркетинговых исследований в фармации: монография. Харьков: НФаУ, 2008. 308 с.

DOI https://doi.org/10.30525/978-9934-26-006-3-29

\section{EVALUATION OF ANTITUMOR EFFECT OF OXAMATE ON METASTATICALLY ACTIVE CELLS}

\author{
Kolesnik D. L. \\ Candidate of Biological Sciences,
}

Senior Researcher at the Laboratory of Molecular and Cellular Mechanisms of Metastasizing

R.E. Kavetsky Institute of Experimental Pathology, Oncology and

Radiobiology of National Academy of Sciences of Ukraine

Pyaskovskaya O. N.

Candidate of Biological Sciences,

Senior Researcher of Laboratory of Molecular and Cellular Mechanisms

of Metastasizing

R.E. Kavetsky Institute of Experimental Pathology, Oncology and

Radiobiology of National Academy of Sciences of Ukraine

\section{Solyanik G. I.}

Doctor of Physico-Mathematical Sciences, Professor,

Head of Laboratory of Molecular and Cellular Mechanisms of Metastasizing

R.E. Kavetsky Institute of Experimental Pathology, Oncology and

Radiobiology of National Academy of Sciences of Ukraine

Kyiv, Ukraine

It is known that high dependence on glycolysis, even in the presence of oxygen (a phenomenon known as the Warburg effect) is one of the unique features of malignant cells. As the main pathway of energy production, glycolysis provides malignant cells with growth benefits and represents a wide range of potential targets for successful therapeutic intervention $[1,2]$. 116 
One such promising target is lactate dehydrogenase (LDH), a key glycolysis enzyme that completes the conversion of glucose to lactate and plays an important role in the initiation and progression of malignancies [3, 4]. It is therefore not surprising that LDH inhibitors, in particular oxamate, can suppress tumor cell proliferation, as evidenced by in vitro and in vivo experiments [4-6].

The aim of the study was to determine whether tumor cells with high metastatic potential in vitro are sensitive to the cytotoxic action of oxamate and whether the LDH inhibitor affects the growth and metastasis of these cells in vivo. Lewis lung carcinoma (LLC) cells obtained from the National Bank of Cell Lines and Tumor Strains of the RE. Kavetsky Institute of Experimental Pathology, Oncology and Radiobiology (IEPOR) of National Academy of Sciences of Ukraine were used as a tumor model. Cells were maintained in RPMI 1640 medium (Sigma, USA) with the addition of 10\% fetal calf serum (FTS, Sigma, USA), $40 \mu \mathrm{g} / \mathrm{ml}$ gentamicin, at $37^{\circ} \mathrm{C}$ in humidified atmosphere with $5 \% \mathrm{CO}_{2}$.

For in vitro experiments, the tumor cells were seeded in the wells of a 96-well plate $\left(1.5 \times 10^{4}\right.$ cells/well $)$. After overnight incubation, medium containing oxamate (Sigma, USA) was added to the cells to a final concentration from 0 to $150 \mathrm{mg} / \mathrm{ml}$, and incubation continued for 1 day. Each oxamate concentration was investigated in 3 replicates. The cells that were incubated under the same conditions without the addition of oxamate served as a control. The number of living cells was evaluated using crystal violet using a plate reader at a wavelength of $595 \mathrm{~nm}$. The cytotoxic/cytostatic activity of oxamate was determined by $\mathrm{IC}_{50}-$ the concentration of the compound, which leads to a $50 \%$ reduction in the number of living cells.

For in vivo experiments, mice bred in vivarium of IEPOR were randomized by weight, divided into three groups and intramuscularly inoculated with LLC cells ( $1 \times 10^{6}$ cells $/ 0.1 \mathrm{ml}$ Hanks solution/mouse). Mice of the 1 st $(n=9)$ and 2 nd $(n=9)$ groups were injected with oxamate in $0.5 \mathrm{ml}$ of saline at a dose of $0.3 \mathrm{~g} / \mathrm{kg}$ and $0.6 \mathrm{~g} / \mathrm{kg}$ of body weight, respectively. Oxamate was administered intraperitoneally daily 5 times/week for 3 weeks. Mice of group $3(\mathrm{n}=11)$, which were injected with saline according to the same scheme and in the same volume, served as controls.

On day 24 after tumor transplantation, the effect of oxamate on primary tumor volume, number and volume of lung metastases, as well as glucose and lactate content, and LDH activity in tumor tissue and blood plasma of tumor-bearing mice was assessed. 
The volumes of the primary tumor and metastases were calculated using routine methods based on the diameter of the tumor or metastasis.

The content of glucose, lactate and LDH level in the test samples was determined using a biochemical analyzer.

Statistical processing of the results was performed using descriptive methods, Mann-Whitney test and methods of nonlinear regression analysis.

The study revealed a concentration-dependent cytotoxic/cytostatic effect of oxamate on LLC cells (Fig. 1). Tumor cells were characterized by heterogeneity in terms of sensitivity to the cytotoxic action of oxamate: about $30 \%$ of cells were resistant to its action. As can be seen from Fig. 1, cell death occurred at concentrations above $16.0 \pm 0.5 \mathrm{mM}$. It was found that the $\mathrm{IC}_{50}$ of oxamate for these cells was $74.8 \pm 3.8 \mathrm{mM}$.

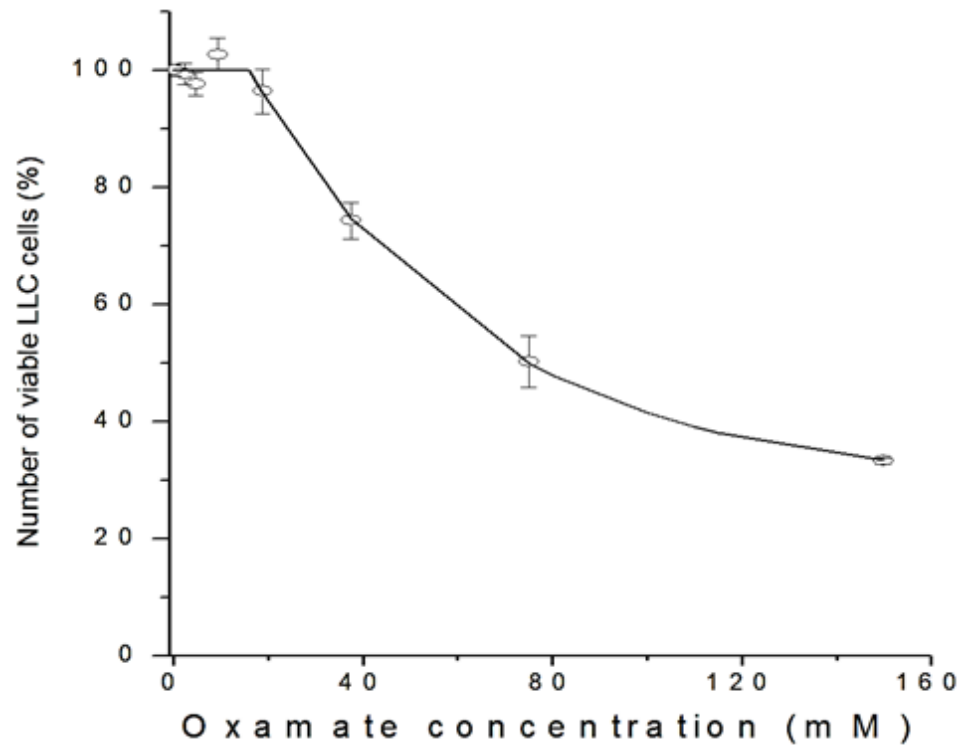

Fig. 1. Number of viable $L L C$ cells as function of oxamate concentrations. Open symbols - experimental data. Lines - fitting curve

The ability of oxamate to exhibit cytotoxic activity against LLC cells was not accompanied by inhibition of LLC growth and metastasis in vivo, at least when it has been administered at doses of $0.3 \mathrm{~g} / \mathrm{kg}$ and $0.6 \mathrm{~g} / \mathrm{kg}$ body weight. Thus, in animals injected with oxamate, the volume of the primary tumor, 
the number and volume of lung metastases on the 24th day after transplantation of the tumor did not differ significantly from similar indices in the control (Fig. 2).

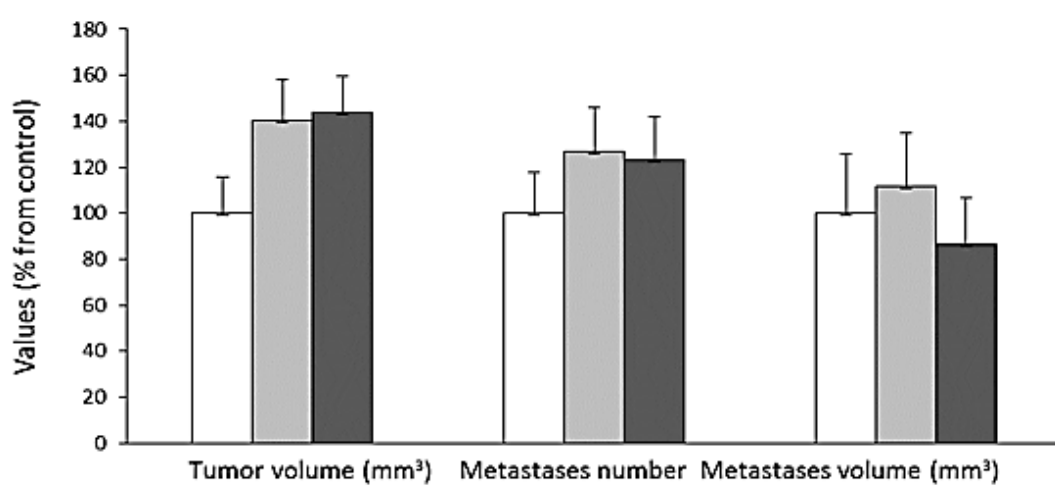

Control $\square$ Oxamate $(0.3 \mathrm{~g} / \mathrm{kg}) \quad \square$ Oxamate $(0.6 \mathrm{~g} / \mathrm{kg})$

\section{Fig. 2. The effect of oxamate on the growth and metastasis of LLC on the 24th day after tumor transplantation.}

It is known that LDH in the blood of cancer patients is usually elevated, which gives reason to consider LDH as a sufficiently informative indicator to monitor the treatment dynamics of patients with some cancer types [7-8]. In this work, it was found that LDH level in both blood plasma and tumor tissue (per $1 \mathrm{mg}$ of protein) in mice treated with oxamate at both doses did not differ significantly from the corresponding index in the control.

At the same time, the assessment of plasma lactate level in experimental mice showed that in animals treated with oxamate at a higher dose, $0.6 \mathrm{~g} / \mathrm{kg}$, this index was $20 \%$ lower $(\mathrm{p}<0.05)$ than in the control. Oxamate-induced decrease in the plasma lactate level in tumor-bearing mice indirectly indicated some inhibition of LDH activity by oxamate in this group of animals.

Conclusions. The cytotoxic/cytostatic activity of oxamate against Lewis lung carcinoma cells in vitro and the lack of its antitumor activity in vivo have been shown. Such effect may be caused by the bioenergetics of metastatically active cells and/or the distribution and metabolism of oxamate in the body due to which the concentration of oxamate sufficient to implement its cytotoxic action is not achieved in the tumor tissue. 


\section{References:}

1. Ganapathy-Kanniappan S., Geschwind J.-F.H. Tumor glycolysis as a target for cancer therapy: progress and prospects. Mol. Cancer. 2013; 12: 152. doi:10.1186/1476-4598-12-152.

2. Savic L.J., Chapiro J., Duwe G., Geschwind J.-F. Targeting glucose metabolism in cancer: a new class of agents for loco-regional and systemic therapy of liver cancer and beyond? Hepat. Oncol. 2016; 3 (1): 19-28.

3. Allison S.J., Knight J.R.P., Granchi C., et al. Identification of LDH-A as a therapeutic target for cancer cell killing via (i) p53/NAD(H)-dependent and (ii) p53-independent pathways. Oncogenesis. 2014; 3: e102. doi:10.1038/oncsis.2014.16.

4. An J., Zhang Y., He J., Zang Z., et al. Lactate dehydrogenase A promotes the invasion and proliferation of pituitary adenoma. Sci. Rep. 2017; 7: 4734. doi:10.1038/s41598-017-04366-5.

5. Li X., Lu W., Hu Y., et al. Effective inhibition of nasopharyngeal carcinoma in vitro and in vivo by targeting glycolysis with oxamate. Int. J. Oncol. 2013; 43: 1710-1718.

6. Yang Y., Su D., Zhao L., et al. Different effects of LDH-A inhibition by oxamate in non-small cell lung cancer cells. Oncotarget. 2014; 5: 1188611896. www.impactjournals.com/oncotarget.

7. Pelizzari Giacomo, Basile Debora, Zago S. et al. Lactate dehydrogenase (LDH) response to first-line treatment predicts survival in metastatic breast cancer: first clues for a cost-effective and dynamic biomarker. Cancers (Basel). 2019; 11 (9): 1243. doi:10.3390/cancers11091243.

8. Forkasiewicz A., Dorociak M., Stach K., et al. The usefulness of lactate dehydrogenase measurements in current oncological practice. Cell. Mol. Biol. Lett. 2020; 25: 35. doi:10.1186/s11658-020-00228-7. 